\title{
A HERMENÊUTICA DE PROFUNDIDADE E SUAS APLICAÇÕES
}

THE DEPTH HERMENEUTICS AND ITS APPLICATIONS

\author{
Heleno Rocha Nazário \\ Mestrando em Comunicação Social pela Pontifícia Universidade Católica do Rio Grande do Sul \\ Jornalista da Assessoria de Imprensa da Universidade Federal do Pampa \\ E-mail: helenorochanazario@gmail.com

\section{Luciana da Silva Souza Reino} \\ Doutoranda em Comunicação Social pela Pontifícia Universidade Católica do Rio Grande do Sul \\ E-mail: luciana.reino@acad.pucrs.br

\section{Rodolfo Manfredini} \\ Mestrando em Comunicação Social pela Pontifícia Universidade Católica do Rio Grande do Sul \\ E-mail: rodolfo.manfredini@gmail.com
}

\section{RESUMO}

A Hermenêutica de Profundidade, na formulação proposta por John B.Thompson como referencial metodológico para a pesquisa das formas simbólicas circulantes em contextos sociais, é o tema deste relato de pesquisa. Informações sobre as influências na composição do método estruturam o caminho para a explicação sobre como as fases da Análise Sócio-histórica, Análise Formal ou Discursiva e a Interpretação/ Reinterpretação podem ser articuladas com outros métodos de análise, e como a teoria de Thompson sobre a Ideologia e as estratégias de construção simbólica a serviço de modos de operação ideológicos pode ser posta em uso como opção metodológica. Aplicações do método em alguns tipos de suportes usados para as formas simbólicas são discutidas na seção final do texto.

Palavras-chave: Hermenêutica de Profundidade. Comunicação. Método.

\begin{abstract}
Depth Hermeneutics, in the form proposed by John B. Thompson as a methodological framework for the research of current symbolic forms in social contexts, is the subject of this research report. Information about the influences on the method of composition structure the way of the explanation of how the phases of the Socio-Historical Analysis, Formal or Discourse Analysis and Interpretation / Reinterpretation can be combined with other methods of analysis. In addition, how
\end{abstract}


the Thompson's theory of ideology and symbolic building strategies in the service of ideological modes of operation can be used as a methodological option. Applications of the method in some types of media used for the symbolic forms are discussed in the final section of the text.

Keywords: Depth Hermeneutics. Communication. Method.

\section{CONSIDERAÇÕES INICIAIS}

A pesquisa na área da Comunicação pode ser direcionada para as diferentes etapas do processo comunicativo: a produção, a circulação, a recepção e o retorno, ou os efeitos, das mensagens no meio social. O referencial metodológico da Hermenêutica de Profundidade ${ }^{1}$, proposto por John B. Thompson, consiste em uma opção válida para as pesquisas nesse campo do conhecimento. Entre suas principais características, estão a organização do trabalho em análises com focos específicos no contexto sócio-histórico e nas formas simbólicas e sentidos contidos nas mensagens, o que favorece a esquematização do trabalho de pesquisa em uma sequência clara; a conexão entre o meio social, em suas circunstâncias, e os sentidos produzidos, veiculados e interpretados pelos indivíduos que habitam o espaço contextualizado, ligação que deve conduzir a uma interpretação da interpretação, ou reinterpretação dos sentidos contidos nas formas simbólicas em análise. Esse percurso hermenêutico é feito ao se completar as etapas da Análise Sócio-histórica, da Análise Formal ou Discursiva e da Interpretação/Reinterpretação.

Também integra o referencial da HP a Interpretação da Doxa, ou Hermenêutica da Vida Cotidiana. Thompson lista esta etapa como básica em relação às demais e a explica como sendo a fase na qual se busca compreender como os indivíduos percebem e entendem as mobilizações de sentidos no bombardeio de mensagens ao qual estão submetidos na sua vida diária. Trata-se de considerar o mundo sócio-histórico (ou a fração dele em estudo) não somente um campo-objeto, inerte e facilmente apreensível pela observação, mas também um campo-sujeito que interpreta as formas simbólicas que percebe e que age, ou reage, de acordo com as interpretações feitas a partir dos sentidos em circulação. Nessa etapa, podem-se empregar técnicas de análise favoráveis ao contato com as pessoas e o estudo das interpretações que fazem das mensagens e formas simbólicas, como a entrevista em profundidade e a técnica de grupo focal, por exemplo.

Essa rápida apresentação de suas características mais imediatas pede algumas explicações: a) O que esse método traz em relação a influências teóricas e metodológicas? b) Como essa proposta metodológica funciona? c) que aplicações são possíveis? 


\section{INFLUÊNCIAS}

John Brookshire Thompson é um sociólogo britânico e docente no Departamento de Sociologia da Universidade de Cambridge, Inglaterra. Sua gama de interesses de pesquisa inclui teoria política e social contemporâneas, sociologia da mídia e cultura moderna, o impacto político e social das inovações tecnológicas na área da Comunicação, dentre outros temas ${ }^{2}$.

Em determinado momento de seus estudos, deteve-se sobre as vertentes da Hermenêutica $^{3}$ no âmbito das Ciências Sociais, e em especial sobre os avanços realizados por Paul Ricoeur e Jürgen Habermas, cada qual em sua corrente teórica, sobre o problema da ligação entre filosofia e linguagem, e as consequências da chamada "virada linguística", a mudança de percepção da Filosofia e de outras áreas das Ciências Humanas sobre o papel da linguagem na constituição da realidade. Outro fator influente nesse desenvolvimento foi o embate entre autores proponentes de uma abordagem acadêmica sobre os problemas sociais segundo o modelo das Ciências Naturais, sob uma percepção positivista, e os que intuíam a natureza especial da linguagem e da complexidade do meio social como objeto de estudo.

Thompson destaca duas correntes da Filosofia Ocidental em especial acerca das abordagens sobre as dificuldades do tema da interpretação. A primeira se origina da Hermenêutica Fenomenológica de Husserl, que combinava os procedimentos interpretativos com a abordagem fenomenológica. Essa corrente teve avanços com os trabalhos de Heidegger e Gadamer; Paul Ricoeur é ligado a essa linha de trabalho. Ele é um dos autores ligados à expressão "Hermenêutica de Profundidade". Thompson retoma a proposta de Ricoeur de que o processo de interpretação seja "mediado por uma gama de métodos explanatórios ou 'objetivantes"', porém aponta que a HP como defendida por Ricoeur enfatiza demais a autonomia semântica do texto - indicando um valor de sentido inerente do texto - e "abstrai muito rapidamente das condições sócio-históricas em que os textos, ou as coisas análogas a textos, são produzidos e recebidos" (2011, p. 362)

A segunda linha de influência é a teoria social crítica, tradição filosófica que é embasada pelos escritos de Kant, Hegel e Marx, e desenvolvida por nomes como Horkheimer, Adorno e, mais recentemente, Jürgen Habermas. Dessa tradição se origina a preocupação com a criticidade que a HP propõe para a fase de Reinterpretação.

Em ambos os veios de influência teórica, Thompson notou a intensidade da preocupação com a função da linguagem como meio de participação do indivíduo no mundo, decorrente da virada linguística. Ricoeur e Habermas tratam da linguagem em suas construções teóricas; enquanto o primeiro a descreve como um meio de expressão do ser, e constituinte de um domínio que é o primeiro de uma série a ser questionada rumo à ontologia na busca pelo significado de textos e símbolos, Habermas situa a linguagem como uma de muitas dimensões da vida social, 
uma dimensão sujeita a deformações provocadas pelo exercício do poder, e assim indica que a análise deve identificar as distorções ideológicas que constrangem a linguagem, ligando esses casos e contrapondo-os com uma comunicação ideal e livre de restrições.

Essas "Hermenêuticas Críticas", como Thompson as nomeia, formam a base teórica e epistemológica para a HP que propõe no livro "Ideologia e Cultura Moderna". Em que pese o cuidado com o desvelamento das formas simbólicas, há a clareza de que esse esforço traz resultados parciais se estiver desvinculado do estudo do contexto sócio-histórico, espaço-temporal em que essas formas são veiculadas e percebidas.

\section{MÉTODO E CONCEITOS}

Como um referencial metodológico geral para a análise das formas simbólicas (THOMPSON, 2011, p.356), dentro do qual diversos métodos podem ser situados e conectados, a HP está organizada em três análises: a Análise Sócio-histórica, a Análise Formal ou Discursiva, e a Interpretação e Reinterpretação.

A análise segundo o método da HP, segundo Thompson ${ }^{4}$, requer alguns cuidados, concernentes ao trabalho de interpretação de dados observados, todos eles conectados ao fato do método tratar como elemento essencial de seus esforços as formas simbólicas que movem sentidos em um meio social. O primeiro é que a análise formal, estatística e objetiva das formas simbólicas, tributária da influência positivista, embora não dê conta da complexidade daquelas no ambiente social, representa um adendo importante para a compreensão dos fenômenos sociais. Isso significa que a quantificação não é necessariamente um problema impeditivo para a articulação de métodos e técnicas de análise que possuam esse viés, como é o caso da Análise de Conteúdo, que conjuga procedimentos quantitativos e qualitativos.

O segundo é a natureza especial da investigação social, uma vez que o campo em estudo já é um campo pré-interpretado, ao contrário do que ocorre nas ciências naturais. Afinal de contas, as pessoas vivendo em sociedade ocupam-se de compreender a si mesmas e de interpretar falas, imagens, textos e ações que ocorrem no seu entorno, que é o mundo sócio-histórico, que além de um campo-objeto a ser observado, mas é também um campo-sujeito, composto de pessoas em constante trabalho de compreensão e interpretação, explica Thompson (2011, p.356). O olhar do hermeneuta deve ter sempre presente que a capacidade de compreensão dos processos simbólicos é algo comum e cotidiano aos seres humanos em sociedade, e não um procedimento especializado do cientista. Assim, quando se faz uma interpretação de um fenômeno social, de uma mobilização de sentido, se está na verdade interpretando algo que já foi interpretado pelas pessoas, é a interpretação da interpretação, ou um re-interpretação. 
Por "formas simbólicas" se deve entender textos, imagens, falas e toda a forma comunicacional na qual se possa organizar uma mensagem, por meio de linguagem, e que contenha sentidos: "[...] uma ampla variedade de fenômenos significativos, desde ações, gestos e rituais até manifestações verbais, textos, programas de televisão e obras de arte" (THOMPSON, 2011, p. 183). Thompson aponta para cinco aspectos das formas simbólicas como forma de explicar porque as formas simbólicas podem ser vistas como fenômenos significativos:

Intencional: as formas simbólicas são produzidas, construídas e veiculadas por um sujeito que busca objetivos ao expressar "o que quer dizer" para um outro sujeito ou grupo de sujeitos. O termo "intencional" quer indicar a ação, a vontade em se expressar por meio de uma forma simbólica, e não exclui as divergências possíveis entre intenção, forma e o sentido percebido pelo receptor, por exemplo;

Convencional: a produção, a circulação e a interpretação das formas simbólicas se dão por meio da aplicação de códigos, regras ou convenções variadas, desde as técnicas até as convenções sociais e relacionais. Inclui as questões entre codificação e decodificação.

$>$ Estrutural: as formas simbólicas possuem estrutura articulada de elementos que se inter-relacionam. Esses elementos integram um sistema simbólico, e é por isso que se torna possível tanto desvelar a estrutura de uma forma simbólica quanto analisar esse sistema simbólico por meio de sua corporificação em uma forma simbólica particular.

Referencial: as formas simbólicas tipicamente se referem a algo, dizem algo sobre alguma coisa, representam alguma coisa. Trata-se da "especificidade referencial" (2011, p.190), ou seja, do fato de que uma forma simbólica se refere a um específico objeto ou situação quando empregada em uma dada ocasião; assim, há figuras e expressões que só adquirem essa especificidade em determinados ocasiões.

Contextual: indica que as formas simbólicas estão sempre "inseridas em processos e contextos sócio-históricos específicos dentro dos quais e por meio dos quais elas são produzidas, transmitidas e recebidas" (2011, p.192). Esse aspecto gera diversas consequências, pois implica as relações sociais específicas em análise, os meios pelos quais as formas simbólicas foram expressas, que traços elas carregam e como esses traços motivam a sua valorização ou desvalorização.

Outra consequência de se estudar o mundo sócio-histórico como campo-sujeito, para Thompson, é a possibilidade de apropriação que as pessoas possuem a partir da compreensão e da interpretação das formas simbólicas e dos sentidos agenciados, o que inclui a ação a partir da 
interpretação dos sentidos. Nisso também as Ciências Sociais diferem das Naturais: nestas, a intervenção e a mudança são provocadas pelo agente externo, o sujeito da pesquisa, seja ele cientista ou tecnólogo, enquanto nas primeiras a complexidade reside na potencial apropriação que as pessoas fazem do que compreendem dos sentidos que percebem nas formas simbólicas, na retroalimentação específica que ocorre no mundo sócio-histórico (THOMPSON, 2011, p.359).

O fato de que os seres humanos, enquanto constituintes do mundo sócio-histórico, estão sempre inseridos em tradições históricas, são parte da história, de contextos sócio-históricos mais amplos (THOMPSON, 2011, p. 360) também deve ser lembrado no processo de análise pela HP. A experiência humana, neste enfoque, é sempre vista como histórica; isso impacta na compreensão do passado como base para a construção do futuro e também como fonte de recursos para mascarar o presente, na noção de tradições inventadas, das quais se perde o rastro da origem. Assim, Thompson aponta esquematicamente para fases de investigação hermenêutica: a Hermenêutica da vida cotidiana, que leva a uma interpretação da doxa, ou seja, a interpretação de como as pessoas opinam, creem e compreendem a partir de sentidos em suas vivências no mundo social; e a Hermenêutica de Profundidade propriamente dita, com as suas três fases: a Análise Sócio-histórica, a Análise Formal ou Discursiva, e a Interpretação/Reinterpretação.

A Análise Sócio-Histórica parte do fato de que as formas simbólicas são criadas e circulam em contextos sociais, espaciais e temporais particulares; é por isso que o objetivo dessa análise é "reconstruir as condições sociais e históricas de produção, circulação e recepção das formas simbólicas" (2011, 366) (grifo no original). Thompson propõe níveis de análise dentro dessa primeira fase da HP com a finalidade de se obter uma compreensão contextual o mais ampla possível:

Situações espaço-temporais - dizem respeito às condições de espaço e aos períodos históricos nos quais as formas simbólicas foram estruturadas, postas em circulação e percebidas pelas pessoas;

> Campos de interação - neste nível se entende o campo de interação como o espaço de posições e trajetórias que determinam algumas das relações e algumas das oportunidades disponíveis. Pode-se entender nesse nível os diferentes tipos de “capital”, as normas e a táticas disponíveis a pessoas, grupos e instituições, incluindo as regras tácitas vigentes naquele espaço;

Instituições sociais - são os conjuntos relativamente estáveis de regras e recursos e suas respectivas relações sociais. Essas instituições devem ser analisadas quanto ao seu desenvolvimento ao longo do tempo; 
Dstrutura social - neste nível o hermeneuta deve considerar as assimetrias e diferenças relativamente estáveis que conformam os espaços de interação e as instituições sociais. Importam aqui as diferenças coletivas e duráveis de distribuição de recursos, poder, oportunidades e possibilidades de realização, e os critérios, categorias e princípios que estão por baixo dessas distinções e que lhes conferem durabilidade e estabilidade.

A Análise Formal ou Discursiva, ao seu turno, ocupa-se das estruturas pelas quais as formas simbólicas são compostas e organizadas nas mensagens, e de como mobilizam sentidos. Nesta etapa da aplicação da HP é possível conjugar outros métodos e técnicas de análise, como a Análise de Discurso, Análise Semiológica Barthesiana, Análise Conversacional, Argumentativa, Análise de Conteúdo. O intuito desse momento será entender como as formas simbólicas estão organizadas de modo a mover sentidos, e quais sentidos estão sendo movidos. Nesses casos de imbricação de técnicas de análise dentro do referencial da HP, é preciso atenção ao tipo de técnica/método, que deve ser adequado ao objeto em estudo. É importante que dê conta de explicar a apresentação das formas simbólicas no material analisado.

A fase de Interpretação/Reinterpretação das formas simbólicas é o momento de retomar os resultados das etapas anteriores com o fito de gerar uma interpretação criativa e crítica, superando as aparências evidentes. Uma premissa importante é a de que a interpretação das mensagens que permeiam o mundo social é uma atividade cotidiana e realizada por qualquer pessoa que viva em nossa sociedade. A diferença entre a leitura do transeunte e a do hermeneuta está na profundidade que alcança com o apoio das análises das formas simbólicas que são disseminadas e do contexto sócio-histórico no qual essas formas circulam e são percebidas e entendidas pelas pessoas.

Outra marca da leitura do hermeneuta: ele interpreta o que já foi interpretado por outros, reinterpreta o que já circulou, e por isso, pode problematizar tanto as compreensões superficiais a partir das formas simbólicas quanto eventuais relações assimétricas, que inspiram as estratégias de construção simbólica; por sua vez, cada forma simbólica pode estar ligada a um dos modos de operação da Ideologia, como se verá na seção seguinte.

Uma característica que também merece atenção é a maleabilidade que a HP possui, por meio da possibilidade de articular diferentes técnicas de análise e métodos para a etapa Formal ou Discursiva, ou do emprego da teoria da Ideologia e das estratégias da Ideologia, também propostas por Thompson. Uma vez que diferentes temas de pesquisa se referem a contextos comunicacionais distintos, essa abertura facilita o emprego da técnica mais adequada ao tipo de objeto e às questões que movem a curiosidade do pesquisador. 
Outra possibilidade disponível no emprego do referencial metodológico da HP é a aplicação das fases de análise e interpretação em um Enfoque Tríplice (THOMPSON, 2011, p. 392-402) acerca das fases de a) produção e transmissão, b) construção e c) recepção e apropriação das formas simbólicas, e de seus sentidos, pelas pessoas e grupos de pessoas aos quais essas construções foram endereçadas. Essa definição de Thompson para o processo comunicativo pode ser combinada com os enfoques de pesquisa sobre o emissor, a mensagem e o receptor. Essa escolha provavelmente levaria a projetos de pesquisa de médio a longo prazo, no caso de um assunto de pesquisa complexo, pela necessidade de repetir as três análises a cada enfoque.

\section{COMUNICAÇÃO EM THOMPSON}

Em relação à comunicação de massa, Thompson começa por questionar os sentidos dessa expressão. "Massa", segundo ele, pode ser um termo enganador, pois pode sugerir uma multidão homogênea e inerte a receber as mensagens; ele prefere deixar aberta a possibilidade de a recepção ser um "processo ativo, inerentemente crítico e socialmente diferenciado" (2011, p. 287-288).

O sentido do termo "comunicação" também é problematizado: Thompson compreende o processo comunicativo midiático como marcado por uma ruptura essencial nos quesitos da espacialidade, da temporalidade e da dialogicidade. Ao contrário da conversa, em que emissor e receptor se engajam em um jogo de alternância de papéis em tempo real, a comunicação via meios massivos não se dá no mesmo espaço e envolve assincronia. Além disso, a possibilidade de retorno do receptor é restrita nesses canais de comunicação de massa, o que enfraquece as chances de diálogo entre as instâncias do emissor e do receptor.

É com esses conceitos preliminares que Thompson vai propor a abordagem sobre os meios de comunicação de massa como definidos pelos seguintes aspectos:

$>$ Produção e difusão institucionalizada de bens simbólicos $=$ as instituições, as empresas voltadas para a comunicação de massa se estruturam para a geração em larga escala de formas simbólicas que são construídas para determinados suportes, em larga escala e com reprodução em geral controlada pelos meios de comunicação. As formas simbólicas são mercantilizadas, seja como produto para consumo ou meio para vender outros produtos;

Ruptura fundamental entre a produção e a recepção de bens simbólicos $=$ as formas simbólicas veiculadas nos meios de comunicação de massa são, em geral, feitas para receptores que estão ausentes no local e momento da produção dessas 
formas, o que implica na mediação das formas simbólicas pelos meios técnicos nos quais elas são veiculadas. Essa mediação, por sua vez, implica um fluxo de mão única emissor-receptor, gerando a indeterminação na instância produtora sobre as respostas dos receptores. Essa indeterminação apontada por Thompson é que faz com que os meios de comunicação busquem estratégias para reduzir essa indeterminação, com fins negociais.

Aumento da acessibilidade das formas simbólicas no tempo e no espaço $=$ refere-se à possibilidade de acesso a essas formas em momentos e espaços diferentes e distanciados do local e momento de produção das mensagens. Esse aspecto depende de fatores como a durabilidade dos meios técnicos escolhidos, da disseminação desses meios técnicos entre as populações, das práticas sociais de consumo de formas simbólicas, entre outros elementos.

Circulação pública das formas simbólicas = as formas simbólicas produzidas pelos meios de comunicação de massa destinam-se a um conjunto plural de receptores cujo acesso aos meios técnicos, em tese ilimitado, na prática se vê conformado pelas condições sócio-históricas de produção, transmissão e recepção, o que também influencia nos modos pelos quais as pessoas se apropriam dos produtos midiáticos. Esse aspecto também se relaciona com as formas de controle sobre a produção de formas simbólicas por parte de governos e outros grupos reguladores.

$\mathrm{O}$ desenvolvimento dos meios de comunicação de massa no século XX, ligado ao processo de reorganização entre as esferas da vida pública e da vida privada, bem como as contribuições de Harold Innis e de Marshall McLuhan para uma teoria da mídia, para resumir arriscadamente o raciocínio de Thompson, o levam a desenvolver teses acerca da análise da ideologia na era das comunicações de massa:

$>$ A análise da ideologia nas sociedades modernas deve conceder ênfase à natureza e ao impacto da comunicação de massa, reconhecendo, porém, que a comunicação de massa não é o único canal para a ideologia;

> desenvolvimento da comunicação de massa aumenta de forma significativa o alcance de operação da ideologia nas sociedades modernas, ao fazer com que as formas simbólicas fiquem disponíveis para audiências extensas e potencialmente amplas dispersas no tempo e no espaço; 
$>\mathrm{O}$ caráter ideológico da comunicação de massa só pode ser analisado por meio do estudo das organizações de comunicação de massa, das mensagens midiáticas e dos contextos e processos específicos de sua apropriação pelos indivíduos receptores;

A variedade de meios de comunicação de massa e a natureza das quase-interações que eles possibilitam definem parâmetros amplos para a aquisição de caráter ideológico pelas mensagens midiáticas, mas esses meios de comunicação em si não constituem essas mensagens como ideológicas.

\subsection{IDEOLOGIA EM THOMPSON}

O método da HP foi proposto para a análise de sentidos veiculados por meio de formas simbólicas no contexto social. Essa definição permite empregar o método para compreender os sentidos veiculados pelos meios de comunicação, havendo a opção metodológica de conduzir o estudo com base na sua teoria da Ideologia e de suas estratégias de operação. Por isso, é preciso dizer que, para Thompson, a Ideologia é sentido a serviço do poder, e estudar a Ideologia "é estudar as maneiras como o sentido serve para estabelecer e sustentar relações de dominação" (2011, p.76). As formas simbólicas podem servir para firmar e manter, ou até para subverter, essas relações assimétricas. A cada mensagem enviada ao público pelos meios de comunicação, como textos, imagens e sons correspondem formas simbólicas pelas quais os sentidos são percebidos e interpretados pelas pessoas.

Os modos de operação da Ideologia, como listadas por Thompson, podem ser apontados nos casos em que um sentido evidencie uma relação de dominação, de assimetria entre pessoas ou grupos, instituições, países. As formas simbólicas representam as relações assimétricas e também as conformam, as definem e as reforçam como tais. Nesta visão metodológica, é possível encontrar formas simbólicas que não estejam vinculadas a um projeto de dominação, mas não se pode delinear uma condição ideológica sem que a ela sirvam formas simbólicas.

A Ideologia, em Thompson, é entendida em uma perspectiva crítica, que coloca os sentidos como marcas comunicacionais de relações assimétricas entre grupos que se diferenciam por características como gênero, etnia, preferência sexual, religiosa, status dentro de uma empresa, organização pública, entre países dominantes e países subordinados, entre faixas sociais e mesmo entre funções profissionais; a lista de conflitos possíveis é virtualmente ilimitada. Onde há tensão entre grupos, também existe troca de sentidos pelas ações de comunicação, ou seja, também há veiculação de ideologias, ou melhor, ocorre a operacionalização de uma ideologia por meio de 
estratégias simbólicas. Isso pressupõe, também, a ocorrência dessas formas, e dessas dominações, em um dado contexto socio-histórico específico, na construção do qual essas relações assimétricas e os sentidos serviram de argamassa.

O conceito de Ideologia de Thompson, em relação ao conceito latente de Ideologia de Marx, expande a possibilidade de relações de subordinação que podem ser desveladas pela análise das formas simbólicas e do contexto para muito além da luta de classes, entendida por Thompson como ainda relevante, mas não a única importante para a compreensão e a busca por alternativas na atualidade. Outra inovação está no teor crítico impresso por Thompson, que não se detém no juízo "verdadeiro/falso" face à realidade material a serviço da classe dominante e da alienação do proletariado, como postula Marx; importa preservar o sentido negativo do termo Ideologia, ligá-lo ao aspecto da subordinação. As formas simbólicas podem ser empregadas ideologicamente para estabelecer e sustentar relações de dominação. Estabelecer, ao criar e organizar essas assimetrias; sustentar, ao manter e reproduzir essas relações por meio da produção e da recepção de sentidos.

Para Thompson, há modos gerais de operação dos sentidos ideológicos, subdivididos em estratégias típicas de construção simbólica que podem mobilizar sentidos de modo a criar uma nova situação relacional ou de reproduzir as condições de uma relação já existente. Thompson (2011, 81-82) alerta: as combinações entre os modos de operação e as estratégias podem variar; a lista de modos e estratégias descrita não é exaustiva, podendo haver outras estratégias em uso para um dado modo de operação da ideologia; finalmente, o fato de se identificar uma estratégia de construção simbólica não significa automaticamente a identificação de um uso ideológico, pelo fato de que nenhuma estratégia é intrinsecamente ideológica. O caráter ideológico se verifica pelo emprego da forma simbólica em um contexto no qual essa forma sirva para firmar ou abalar uma relação assimétrica. A lista apresentada por Thompson contempla cinco modos gerais e treze estratégias de construção simbólica, agrupadas em função da tipicidade dessas ligações $(2011,81)$ como exposto no Quadro 1.

\section{Quadro 1: Modos gerais e estratégias de construção simbólica segundo Thompson}

\begin{tabular}{|c|c|}
\hline Modos gerais & Algumas estratégias típicas de construção simbólica \\
\hline Legitimação & Racionalização; universalização; narrativização \\
\hline Dissimulação & Deslocamento; eufemização; tropo \\
\hline Unificação & Estandardização; simbolização da unidade \\
\hline Fragmentação & Diferenciação; expurgo do outro \\
\hline Reificação & Naturalização; eternalização; nominalização/passivização \\
\hline
\end{tabular}

As ligações operacionais entre os modos e as estratégias, conforme Thompson, são como segue: 
A Legitimação constitui um modo pelo qual relações de dominação podem ser criadas e mantidas. Se essas relações são vistas como justas e válidas dentro de um sistema de regras, tradições ou pela autoridade, mais fácil é considerá-las como dignas de serem preservadas e apoiadas. Com base em Max Weber, Thompson aponta que afirmações de legitimação podem estar fundadas em argumentos racionais (apelo ao vigor de regras), tradicionais (apelo ao teor sagrado da tradição) e carismáticos (apelo ao caráter único e excepcional de uma pessoa em exercício de autoridade). A essas formas de legitimação Thompson liga as estratégias de racionalização, que consiste em persuadir por meio de uma cadeia de raciocínio que defende ou justifica um ponto de vista, uma instituição ou relações; de universalização, por meio da qual se expõe acordos, relações, vantagens, que em tese estão acessíveis a todos que se mostrem aptos, embora atendam direta e imediatamente a determinados grupos ou indivíduos; e de narrativização, que vem a ser a composição de histórias que conformam o presente como parte de uma tradição eterna, sagrada - e por isso, imutável - com base em uma configuração do passado.

O modo da Dissimulação envolve o emprego de estratégias de construção simbólicas que facultem ao emissor ocultar, negar e obscurecer aspectos das relações assimétricas, buscando manter as aparências frente à audiência. Thompson conecta esse modo a algumas estratégias típicas: o deslocamento, visível quando um termo que normalmente se refere a um objeto ou pessoa é usado para a referência a outro objeto ou pessoa, gerando assim a transferência dos sentidos positivos ou negativos conotados no termo em seu emprego original; a eufemização, notada na descrição ou redescrição de instituições, situações, relações sociais e pessoas de forma a erigir uma valoração positiva; e o uso do grupo de estratégias que Thompson denomina tropo, pelo fato de reunir os usos figurativos da linguagem, em especial a sinédoque (uso de um termo que significa uma parte de um todo para se referir de modo genérico ao todo), a metonímia (uso de um termo para se referir a outro por meio de uma relação semântica entre os dois) e a metáfora (uso de um termo para significar a outro por conta da semelhança por analogia entre os dois, embora sejam de campos semânticos diferentes).

O modo da Unificação, segundo Thompson, funciona por meio da construção de uma identidade coletiva urdida de forma a relativizar, ao menos momentaneamente, as diferenças e querelas entre os grupos aos quais a mensagem se destina. Uma estratégia é a padronização. As formas simbólicas são organizadas e criadas com um referencial que se impõe como sendo um fundamento geral ao qual os diferentes grupos componentes do público são instados a aderir. Outra estratégia listada é a simbolização da unidade, que consiste no emprego de símbolos criados para sintetizar a unidade pretendida, como bandeiras, emblemas, lemas, hinos. Thompson exemplifica um uso dessa estratégia em articulação com a estratégia de narrativização: um símbolo 
proposto como representativo de uma comunidade, um coletivo, pode estar ligada e reforçada por uma narrativa que se pretende histórica, construindo uma noção de ancestralidade e tradicionalidade em torno do fim pretendido, que pode ser a instituição e manutenção de uma relação assimétrica.

Uma quarta maneira de operação da Ideologia, para Thompson, é a Fragmentação. O foco das estratégias alinhadas com esse modus operandi é segmentar os grupos que podem afetar a balança de poder, por meio da separação de indivíduos ou grupos que são ameaças aos dominantes, ou redirecionando os ânimos opositores para um alvo desenhado para ser visto como ameaça comum, mal maior, perigo geral. A primeira estratégia é a diferenciação: trata-se de enfatizar as diferenças entre grupos e pessoas, fortalecendo todos os aspectos que os enfraquecem como opositores do status quo, com o fito de impedi-los de opor desafio real ao poder estabelecido. O expurgo do outro é ação estratégica de construção simbólica de um inimigo perigoso o bastante para incitar o direcionamento das forças do público para o combate e a resistência a essa ameaça. Thompson indica que é comum a conjugação das estratégias de expurgo do outro e das estratégias ligadas ao modo de unificação. O inimigo é descrito simbolicamente de forma a representar imensa ameaça à coletividade, que deve então reunir suas forças e repelir o perigo.

O quinto modo de operação da Ideologia, na lista inicial apresentada por Thompson, é a Reificação, o ofuscamento ou a retirada dos aspectos processuais e históricos das relações de dominação, que são então apresentadas pelas construções simbólicas como coisas (daí o nome do modo) e, por isso, imutáveis, naturais, permanentes. Ocorre a implantação de uma noção de "sociedade a-histórica" no seio de uma sociedade que é, necessariamente, histórica. Há o ocultamento da processualidade histórica na sucessão de relações sociais, assimétricas ou não, e em seu lugar é exposta a situação presente como sendo uma constante. Uma das estratégias usadas para esse fim é a naturalização de um estado de coisas criado social e historicamente por meio de uma exposição simbólica que indique a naturalidade e a inevitabilidade desse estado de coisas. A eternalização age especificamente na retirada do aspecto histórico das relações em questão, que passam a ser vistas como imutáveis, recorrentes, afirma Thompson; assim, tradições e instituições "parecem prolongar-se indefinidamente em direção ao passado, de tal forma que todo traço sobre sua origem fica perdido e todo questionamento sobre sua finalidade é inimaginável" (2011, 88). As formas simbólicas criadas para esse fim não apenas instauram essa aura de eternidade sobre tradições e instituições e, consequentemente, sobre as relações de poder aí articuladas; sua repetição consolida esse halo e enrijece o aspecto da tradição ancestral, quase sacralizada, que dificulta as mudanças nas relações assimétricas. Outras estratégias listadas como conectadas com 
o modo de reificação são a nominalização e a passivização. Enquanto a primeira é a transformação de ações em nomes, em geral dos atores aos quais se quer dar mais importância na esfera de ação, a passivização funciona como um apagamento dos atores por meio do uso de verbos na voz passiva. Assim, essas estratégias deslocam a atenção do leitor, ouvinte ou espectador para certos aspectos da mensagem, em detrimento de outros, apagando as referências a atores, contextos temporais e espaciais. Esses procedimentos também expõem processos como coisas, esmaecem ou eliminam as nuances de atores e ações e mostram o tempo como sendo permanentemente presente.

Thompson reforça o alerta de que essa proposta de modos de operação e estratégias da Ideologia deve ser adotada como uma compilação de "orientações gerais que podem facilitar a pesquisa de um tipo mais empírico ou histórico" (2011, 89), uma vez que as estratégias de construção simbólica são "os instrumentos com os quais as formas simbólicas, capazes de criar e sustentar relações de dominação, podem ser produzidas" (2011, p. 89), são ferramentas com as quais se pode mobilizar o sentido. No entanto, é preciso lembrar que as formas simbólicas não são ideológicas em si; a questão sobre se "servem para sustentar relações de dominação ou para subvertê-las" (2011, p. 89) só pode ser respondida pelo estudo de como essas formas simbólicas particulares funcionaram em determinado contexto sócio-histórico, como são interpretadas pelas pessoas em seus diversos espaços de interação social em seus cotidianos.

\section{APLICAÇÕES POSSÍVEIS}

A organização metodológica da HP é flexível a ponto de permitir sua aplicação em diferentes tipos de estudo na área da Comunicação. Com a adoção da proposta do Enfoque Tríplice, a capacidade explicativa pode aumentar, pois o intuito passa a ser interpretar os movimentos de sentido em três instâncias comunicacionais, conforme Thompson: a produção e circulação de mensagens, a construção de formas simbólicas e a recepção e apropriação dessas formas simbólicas pelos indivíduos. Isso conduz a uma visão processual da Comunicação, perspectiva mais fértil em termos de explicações e mais próxima do que acontece no cotidiano atual e nos contextos comunicacionais.

Um exemplo é aportado por Müller (2015, p. 119-120), que indica o uso das etapas da Interpretação da Doxa, da Análise Sócio-histórica, Análise Formal ou Discursiva e da Reinterpretação em uma pesquisa de longo prazo sobre Mídias e Fronteiras, nos quais a HP forneceu a base metodológica na qual técnicas e métodos foram articulados conforme os ciclos do estudo abordavam diferentes instâncias do processo comunicacional: Análise de Conteúdo, Entrevista em Profundidade, Grupo Focal. Com esses recursos, a pesquisadora abordou os 
contextos sociais e culturais das populações fronteiriças, a imprensa que atua junto dessas comunidades e os sentidos que circulam por meio das notícias publicadas ali.

Nancy Vianna (2013) empregou as três etapas da HP para interpretar campanha publicitária da prefeitura de Porto Alegre que foi realizada em 2010, como forma de apresentar a “cidade do futuro" e preparar a opinião pública local para as obras programadas. Com a conjunção de HP e a Análise Semiológica conforme Roland Barthes, Vianna expôs as manobras de construção dos vídeos integrantes da campanha e as contradições entre as propostas e as realidades que se pretendia mudar.

A pesquisa de doutoramento de Vera Raddatz (2009) sobre as rádios de fronteira foi baseada metodologicamente na HP. Com esse referencial, a pesquisadora interpretou as práticas socioculturais empregadas em rádios web situadas nas fronteiras do Brasil com a Argentina, o Paraguai e o Uruguai, em um movimento que liga a identificação cultural desses espaços com o aspecto da disponibilidade global das formas simbólicas veiculadas pela Internet.

\section{VANTAGENS E DESVANTAGENS}

Dentre as potencialidades que a HP aporta a um estudo, está a atenção para com duas fontes de distorção na pesquisa social. Como apontam Veronese e Guareschi (2006), Thompson quer se prevenir contra duas falácias: a) internalismo, que consiste em analisar as formas simbólicas sem considerar o contexto no qual são produzidas e recebidas, o que implica tratar o texto como analisável em si mesmo, ignorando as marcas sócio-históricas das suas condições de produção; b) reducionismo, que é o extremo oposto, analisar a forma simbólica somente em função das condições sociais de produção e reprodução. A organização das etapas de Análise Sócio-histórica e de Análise Formal ou Discursiva como obrigatórias no enfoque da HP visa evitar esses enganos. Outro bônus derivado da organização das etapas é a geração de uma estrutura lógica clara para a exposição dos resultados.

Em geral, a HP possui em seu referencial uma boa facilidade de articulação de técnicas e conceitos, refletindo a postura aberta de seu sistematizador para o emprego de diferentes recursos na solução de problemas. A inserção da Hermenêutica da Vida Cotidiana como etapa preparatória é um bom exemplo. Ao indicar o uso de técnicas ligadas ao método etnográfico, Thompson facilita ao pesquisador a aproximação qualificada ao seu tema de estudo, iniciando com o entendimento de como o público de interesse opina, crê e interpreta as formas simbólicas em análise. Essa etapa enriquece a percepção do hermeneuta e faculta a escolha das técnicas que melhor se adaptem ao problema visado. 
Outro ponto da HP em que ocorre liberdade metodológica é a Análise Formal ou Discursiva. Ao valorizar a preocupação com a estrutura das formas simbólicas e sua organização em uma mensagem, o hermeneuta pode novamente optar por técnicas e métodos que resolvam as dúvidas em tela. As opções que mesclam os vieses qualitativo e quantitativo, como a Análise de Conteúdo, por exemplo, são permitidas uma vez que Thompson considera que análises formais, objetivas e mesmo estatísticas fornecem dados importantes, porém parciais e por isso, só podem ser complementares em relação aos dados qualitativos, ligados ao sentido e à interpretação.

A aplicação da HP para estudos voltados aos contextos comunicacionais inovados pelas tecnologias de comunicação e informação (TICs), como webjornalismo e redes sociais na Internet, apenas como exemplos, deve levar em conta que no momento da proposição da HP, em 1990, Thompson tinha consciência de que ocorreriam mudanças que estavam, naquele momento, sendo delineadas. No entanto, isso ocorreu no princípio da Internet comercial, da World Wide Web, cuja expansão aumentaria intensamente a partir de 1992 (Cohen-Almagor, 2011) e outras inovações que hoje são conhecidas, mas que eram efervescentes e pouco claras em termos das transformações societais e culturais que favoreceriam.

Por isso, as inovações que o sociólogo aborda no momento da proposição da HP são as que afetaram a televisão no que tange à transmissão e à recepção das mensagens: a) o gravador videocassete domestico; b) o surgimento dos sistemas a cabo e a variedade de canais; c) a transmissão via satélite. Naquele momento, ao abordar os suportes que eram conhecidos e disseminados na época, Thompson verifica a ruptura espacial e temporal que a comunicação midiática estabelece entre emissor e receptor e menciona a escassa abertura para o diálogo e o feedback do receptor ao emissor, questões que hoje apresentam configuração diferente na comunicação mediada por computador e em especial nos contextos comunicacionais via web. Por isso, é importante buscar a fundamentação teórica com base em autores que abordem esses processos contemporâneos, complementando a visão de Comunicação com as inovações mais recentes.

Outro cuidado necessário, porém, é com a seleção do quanto avançar na contextualização sócio-histórica, empregando marcos restritivos conectados à forma simbólica em análise. Sem uma delimitação adequada, corre-se o risco de uma recuperação extensa de contexto, na qual a perda de foco é um risco real.

É preciso ter em mente que o hermeneuta também integra o campo social; por isso, além de sua interpretação ser uma reinterpretação, ela também é uma das interpretações possíveis. Distingue-se das demais pelos procedimentos que lhe dão profundidade, mas é gerada por um indivíduo que também está imerso em uma circunstância sócio-histórica específica. 
A aplicação adequada de todas as etapas da análise da HP pode demandar um período mais extenso, o que é um fator limitante. A análise sócio-histórica pode demandar grande trabalho de documentação; a Análise Formal ou Discursiva, pela diversidade de articulações, requer cuidado nas escolhas de técnicas e depende estruturalmente dos resultados da primeira etapa; e a Reinterpretação pede olhar atento e sereno para os resultados das análises anteriores. Isso pode fazer com que a HP não seja uma boa escolha para projetos de curto prazo, sob risco de negligência em alguma das fases. A realização de algumas das análises, sem completar o ciclo da HP, gera uma visão parcial e potencialmente equivocada, além de não respeitar o método, o que ocasiona perda de tempo e de eficiência.

\section{NOTAS}

1 Doravante, o método será referido pela sigla HP.

${ }^{2}$ Conforme currículo disponível no site do Departamento de Sociologia de Cambridge: http://www.sociology.cam.ac.uk/people/academic-staff/jthompson.

3 As questões relativas ao entendimento e à interpretação de um objeto para além de sua aparência são antigas, tanto que o termo "hermenêutica" vem do vocábulo grego "hemeneuein", que remete no sentido ao trabalho de interpretar, e na forma ao deus grego Hermes (Mercúrio, na posterior apropriação romana), divindade de múltiplas atribuições: protetor dos comerciantes e das estradas, dos ladrões, adivinhos e arautos, mensageiro entre o Olimpo e os homens.

4 Refere-se aqui ao fato de Paul Ricoeur ter proposto uma Hermenêutica de Profundidade; Thompson resgata a proposta, mas nela critica o afastamento, no procedimento de análise, do contexto sócio-histórico nos quais os textos circulam. Dessa proposta e da crítica é que Thompson constrói sua proposta de HP.

\section{REFERÊNCIAS}

COHEN-ALMAGOR, Raphael. Internet History. International Journal of Technoethics, 2(2), p. 45-64. Hull University, 2011. Acessível em <http://www.hull.ac.uk/rca/docs/articles/ internet-history.pdf $>$ Captado em 22. Jun 2015.

MÜLLER, Karla Maria. Mídia Local Fronteiriça. In: RADDATZ, Vera Lúcia Spacil; . Comunicação, Cultura e Fronteiras. Ijuí: Editora da Unijuí, 2015.

RADDATZ, Vera Lúcia Spacil. Rádio de Fronteira: da cultura local ao espaço global (tese). UFRGS, 2009.

THOMPSON, John B. Ideologia e Cultura Moderna. Teoria Social Critíca na Era dos meios de comunicação de massa. Petrópolis, RJ: Vozes, 2011. 
VERONESE, Marília Veríssimo; GUARESCHI, Pedro Arcides. Hermenêutica de Profundidade na Pesquisa Social. Ciências Sociais Unisinos, 42 (2), p.85-93, maio/ago 2006. Acessível em $<$ http://revistas.unisinos.br/index.php/ciencias_sociais/article/view/6019/3194> . Captado em 27 jun 2015.

VIANNA, Nancy Bazán. A comunicação e o futebol: um olhar hermenêutico sobre os discursos publicitários da 'Cidade do Futuro". (dissertação) Porto Alegre: PUCRS, 2013. Acessível em http://hdl.handle.net/10923/2113 